\title{
The Onset of Civil War: Combining Various Scholarly Research Methods to Arrive at A Single, Unified Explanation of Why Civil Wars Occur
}

\author{
Sugumaran Narayanan \\ Department of Political Science, Midwestern State University, Texas, USA
}

(Received 08 November 2018, accepted 31 May 2019)

https://doi.org/10.36224/ijes.120201

\begin{abstract}
Historically, Southeast Asia has been among the most peaceful regions of the world. In the last sixty years, however, the populations of Southeast Asia have been torn apart by ravaging civil wars. What could be causing the high number of ethno-religious civil wars in Southeast Asia? To understand this, I use three different methods, two of which I have already employed in previous researches - quantitative (statistical) and traditional case studies. The third, using personal interviews with direct participants of conflict, is the focus of this study. This, combined with the results obtained from the other two methods, will highlight the causes of civil wars in Southeast Asia. While a number of studies have attempted to answer the race-religion-civil war nexus puzzle (none have used all three methods-quantitative, traditional case studies, and personal interviews), and none has specifically addressed Southeast Asian civil wars using all three methods.
\end{abstract}

\section{Introduction}

This paper was motivated by the seriousness of ethno-religious civil conflicts, like the ones currently occurring in Burma, Indonesia, and the Philippines, and previous conflicts like the ones in East Timor and Aceh in Indonesia and the communist insurgency in Malaysia. A great number of articles and books have been published pertaining to the topic, yet there appears to be little consensus on what causes such conflicts. The reducing trend of international conflict replaced by the increasing numbers of civil conflicts shifted attention to this area of conflict study. There were 36 armed conflicts in 2009. All were civil conflicts and none were interstate [1].

\section{Literature review of civil conflict}

Civil conflict literature boasts three major explanations as to why such conflicts happen.

\subsection{Greed}

The first theory explaining the onset of civil conflicts argues that greed, the desire for private gain, causes it. This idea treats rebellion as a business enterprise, where rebel leaders seek gains from the war [2].

\subsection{Grievance}

The grievance idea came about as a result of ideas from different scholars who argued that grievance instead of personal greed is the cause of civil war. Grievance may arise out of 
dissatisfaction over allocation of resources, or over repressive regime/political rights, territorial struggles, the injection of members of an alien ethnic group into one's territory, or even through mere envy over the success of rival groups.

\subsection{Opportunity}

A more recent explanation of why civil wars occur was put forward by [3], who argued that a better equipped and stronger government can control the onset of conflict (the state capacity explanation). But, instead of lootable resources and male schooling rates being the channel for opportunity, as projected by [2], [3] found that states with unstable and improper management, and weak armed and domestic (police) forces contribute to it.

Other theories have been put forward. For specifically ethno-religious conflicts, the main theories are primordialism, instrumentalism, clash of civilizations, and modernization.

\section{Research design/methodology}

\subsection{Goals and methods of the field personal interviews}

The second method (statistical analysis) complements the first (qualitative personal interview). No studies have used three methods - quantitative, case studies, and personal interviews $[4,5])$. The interviews provide direct contact with parties involved in the conflicts, and the goal is to produce an organized, balanced, comprehensive, and fair research that elicits information in its totality.

There are three major objectives for the qualitative study: (a) obtain firsthand information on why these conflicts happened from the people who make the decisions to go to war; (b) obtain firsthand information on why these conflicts are still unresolved, from the decisionmakers themselves; and (c) design better approaches to understanding civil conflicts, not as ends, but as a means to a larger, long-term study of Southeast Asian civil conflicts. To achieve these objectives, interviews are carried out with each country's political leader focused on what the leader thinks caused previous and/or current civil conflicts within the country. The opinions of the countries' elected political leaders will be compared to other government leaders. Both sets of opinions will then be compared to the opinions of the rebel groups. It is then analyzed and compared with causes of civil conflict with previous research (the quantitative method). This provides a list of common causes of Southeast Asian conflicts. The information will either support the theories already developed by scholars in the field or dispute them. For instance, on Islamic conflicts, [6] and [7] find Islam to be conflict-prone while [8] disagrees.

A carefully worded questionnaire was prepared, and the questions are directly connected to the role of the usual correlates of war in Southeast Asian civil conflicts. The interviewsincluded discussions with the following individuals: Dr Steve Rood, the only American mediator in the current MILF-Government of Philippines formal peace talks. In the Philippines, Noynoy Aquino, President of the Philippines and Nur Misuari, Chief of Moro armed rebel group MNLF and Mohagher Iqbal, Chief Mediator for Islamic armed rebel group MILF. In Indonesia, then Aceh rebel leaders (now leaders of Aceh autonomous

province), including Tengku Hasan di Tiro (just before he passed away) and Mr Malik 
Mahmud, now GAM's leader, after the death of Tengku di Tiro. In Malaysia, Tun Dr Mahathir Mohamad former Prime Minister of Malaysia at the time of interview. Attempts were made to meet with Chin Peng, former Malaysian communist insurgency leader. In Thailand, Col. Kasturi Mahkota, leader of the armed group, PULO.

What I propose to do is to build an inventory of transcripts of personal interviews of all former and current parties directly involved in these conflicts. This, combined with the results obtained from the other two methods, will highlight the causes of civil conflicts in Southeast Asia, bringing to the surface the dynamics behind these causes, therefore allowing policy-makers to consider the causes of civil conflict, which will contribute to tailoring policies accordingly. For example, the quantitative method revealed that, as the percentage of Muslims in a country exceeds 74 percent, the likelihood of conflict increases significantly. When the ethno-religious fractionalization of a country increases, the likelihood of conflict also increases with an inverted U-shaped relationship. It also showed that countries imposing cultural, ethnic, or religious restrictions on its citizens have a significantly higher likelihood of any form of conflict. Personal interviews can confirm or dispute these. There are various factors (such as "glory in conflict" and "rebel/government leader satisfaction") that are impossible to convert into numbers in quantitative research. Personal interviews will be able to tackle these variables. Variables that are easily quantifiable in quantitative research, such as, "degree of restrictions," are reinforced by talking to interviewees who accurately interpret them. The personal interviews should shed some light on this.

\subsection{The quantitative portion of the research}

\subsubsection{Definitions}

The paper follows the definition of armed conflicts as defined by UCDP/PRIO [9]. An armed conflict is

- A contested incompatibility that concerns government or territory or both, where the use of armed force between two parties results in at least 25 battle-related deaths.

- Of these two parties, at least one has to be the government of a state. Interstate armed conflict occurs between two or more states. Intrastate (internal) armed conflict occurs between the government of a state and internal opposition groups.

The unit of analysis is the country-year, coded " 1 " for all country-years with outbreaks that has a minimum of 25 casualties and " 0 " otherwise.

\subsubsection{Observations}

There are 7390 country-years from 1945 to 2004 and a cross-sectional time series (panel) data containing 156 states.

\subsubsection{Description of variables and sources_-Dependent Variables}

Outbreak of Conflict: Outbreak of conflict is denoted by onset, which is the base dependent variable, covering all types of conflicts.

\subsubsection{Description of variables and sources-Independent Variables}

Priorwar: did state experience previous conflicts; Official religion: existence of a state 
religion; Restriction: the presence of ethno-religious restrictions; Ethfrac: the ethnic fractionalization within a country; Relfrac: religious fractionalization within a country; Laglogpop: total population of the country in 1000s; Polity2: democracy score, a 21-point scale, ranging from -10 to +10 ; Laggdpen: per capita income of a country in 1000s; Lagoil: oil exporters.

\subsubsection{Estimation}

The model was analyzed employing the logistic regression estimation method of analysis, dependent variables are binary,

$$
\mathrm{Y}=\beta_{1} \mathrm{X}_{1}+\beta_{2} \mathrm{X}_{2}+\ldots+\beta_{\mathrm{k}} \mathrm{X}_{\mathrm{k}}+\mathrm{e}
$$

However, since we are using time series data, all equations may be expressed, in accordance with time series designs, as

$$
\mathrm{Y}_{\mathrm{it}}=\alpha+\beta_{1} \mathrm{X}_{1 \mathrm{it}}+\beta_{2} \mathrm{X}_{2 \mathrm{it}}+\ldots+\beta_{\mathrm{k}} \mathrm{X}_{\mathrm{kit}}+\mathrm{e}_{\mathrm{it}}
$$

\section{Results}

\subsection{Quantitative results}

Table 1 shows the analysis of the variables. The results in Table 1 shows that countries imposing ethno-religious or cultural barriers on citizens will have a bigger likelihood of conflict. Ethnic fractionalization increases the likelihood of conflict. However when the variable's square term is included in the equation, an inverted U-shaped relationship emerges. As expected, an inverted U-shaped relationship also emerged with the democracy variable, further reinforcing [10]. Consistently, in all results, larger population size and being an oil exporting country contribute to increased expectation of conflict. It is interesting to note that the only factor that reduces the likelihood of armed internal conflict is GDP per capita. The higher a country's per capita income, the lower the likelihood of a conflict outbreak. This is probably the most robust finding in the civil war literature-population size and GDP per capita have consistently been cited to affect civil war

Table 1: Determinants of Civil Conflict, 1946-2004

\begin{tabular}{|l|c|}
\hline & $\begin{array}{c}\text { Onset } \\
(\text { General/Worldwide })\end{array}$ \\
\hline Prior War & $.014(.178)$ \\
\hline Has Official Religion & $.118(.184)$ \\
\hline Restrictions & $.464 *(.198)$ \\
\hline Ethnic Frac. & $4.668^{* * *(1.307)}$ \\
\hline Lag Log of Population & $.353^{* * *}(.058)$ \\
\hline Lag GDP Per Cap. & $-.155^{* * *}(.043)$ \\
\hline Lag Oil & $.572 *(.205)$ \\
\hline Polity2 & $.030^{*}(.012)$ \\
\hline Polity2 Squed. & $-.006^{*}(.003)$ \\
\hline Ethnic Frac. Squared & $-3.584 * *(1.378)$ \\
\hline Constant & $-7.682^{* * *}(.634)$ \\
\hline \multicolumn{1}{|c|}{$\mathrm{N}$} & 6452 \\
\hline
\end{tabular}




\subsection{Qualitative results}

The table below shows a summary of the answers provided by the main respondents when they were interviewed during the fieldwork carried out in Southeast Asia. In the first column are respondents who participated in the interviews referred to as "actors" of conflict, as mentioned previously. The second column describes what they thought were the source of the conflict. A respondent who cited more than one source of conflict were asked to rank the sources which are found in column three. Number 1 in column three is the most important source followed by number 2 as the next most important, and so on and so forth.

Table 2: Summary of results obtained from qualitative research portion

\begin{tabular}{|c|c|c|}
\hline Actor & Source of Conflict & Rank \\
\hline $\begin{array}{l}\text { Malik Mahmud, } \\
\text { GAM, Indonesia }\end{array}$ & $\begin{array}{l}\text { - History/colonial/invasion } \\
\text { /conquering of locals } \\
\text { - Refusal of } \\
\text { Acehnese/Muslims to be } \\
\text { ruled by others } \\
\text { - Rights infringed/stripped }\end{array}$ & $\begin{array}{l}\text { A combination but } \\
\text { 1. Loss of political power from } \\
\text { invasion/conquering of locals } \\
\text { 2. Injustice/unequal treatment }\end{array}$ \\
\hline $\begin{array}{l}\text { President Noynoy } \\
\text { Aquino, the } \\
\text { Philippines }\end{array}$ & $\begin{array}{ll}- & \text { Corruption } \\
\text { - } & \text { Insincerity of all parties } \\
\text { (controls) }\end{array}$ & $\begin{array}{l}\text { 1. Economic barriers } \\
\text { 2. Instrumentalism but not } \\
\text { necessarily Islamic } \\
\text { 3. All others are causes but arise out } \\
\text { of economic barriers } \\
\text { 4. Ethno-religious factors: No }\end{array}$ \\
\hline $\begin{array}{l}\text { Prof. Nur Misuari, } \\
\text { MNLF, the } \\
\text { Philippines }\end{array}$ & $\begin{array}{l}\text { - History/colonial/invasion } \\
\text { /conquering of locals } \\
\text { Refusal of } \\
\text { Moros/Muslims to be } \\
\text { ruled by others }\end{array}$ & $\begin{array}{l}\text { A combination of factors but } \\
\text { 1. Any by-product of colonialism are } \\
\text { important factors } \\
\text { 2. Discrimination and Poverty (even } \\
\text { this is a by- product of } \\
\text { colonialism) }\end{array}$ \\
\hline $\begin{array}{l}\text { Dr Steve Rood } \\
\text { (American mediator } \\
\text { in the GPh-MILF } \\
\text { mediation) }\end{array}$ & - & $\begin{array}{l}\text { Land conflict, therefore mostly } \\
\text { 1. Economic, and } \\
\text { 2. Primordial }\end{array}$ \\
\hline $\begin{array}{l}\text { Dr. Mahathir } \\
\text { Mohamad, former } \\
\text { Prime Minister of } \\
\text { Malaysia }\end{array}$ & $\begin{array}{l}\text { - } \text { The demand for equal } \\
\text { rights } \\
\text { Challenging majority } \\
\text { special rights } \\
\text { - Unwilling to convert to } \\
\text { majority culture, } \\
\text { language, ways } \\
\text { Liberal democracy: free } \\
\text { speech etc }\end{array}$ & $\begin{array}{l}\text { 1. Race/Racial issues } \\
\text { 2. Economic: as important as race but } \\
\text { economic usually amplified by race } \\
\text { and when so, it becomes explosive } \\
\text { 3. Next is barriers but this depends on } \\
\% \text { minority population } \\
\text { 4. Primordialism depends on economic } \\
\text { 5. Ideology before, now no more but. } \\
\text { Was indirectly dependent on economic }\end{array}$ \\
\hline $\begin{array}{l}\text { Colonel } \\
\text { KasturiMahkota, } \\
\text { PULO, Thailand }\end{array}$ & $\begin{array}{l}\text { - History/colonial/invasion } \\
\text { /conquering of locals } \\
\text { Refusal of } \\
\text { Malays/Muslims to be } \\
\text { ruled by others }\end{array}$ & $\begin{array}{l}\text { 1. Thailand does not treat Malays as } \\
\text { one of them } \\
\text { 2.Discrimination/injustice/unequal } \\
\text { treatment/unequalstandards } \\
\text { 3. Barriers/restrictions }\end{array}$ \\
\hline
\end{tabular}


Comparing quantitative and qualitative results reveals some interesting findings. In the qualitative the most frequently cited cause of conflict is inequality or discrimination or described as barriers to progress. This is in line with quantitative research. The second most common result are history and the refusal to be governed by others. The fieldwork provided some important insights into these aspects because these variables were not tested in the quantitative study; this is interesting revelation previously not analyzed. Variables like the refusal to be governed by others is not easily tested in quantitative research, similar to testing variables such as glory or happiness. The next most common factor cited was a weak government. This was cited by two respondents. Only one respondent cited corruption as a conflict-causing factor while one other respondent cited liberal democracy as a cause. This goes completely against the quantitative research as the result of the quantitative study showed that very democratic countries and very autocratic countries have the least likelihood of war. If the respondent had stated that a country undergoing transition to democracy is a correlate of war, it would make sense because the quantitative literature showed that semidemocratic states have the highest likelihood of war. None of oil, ethno-linguistic fractionalization, high population, or official religion was cited as conflict-causing variables by the respondents even though the first three of the four factors above came up as statistically significant in the quantitative portion.

\section{Conclusion}

These scholars suggested combining quantitative studies with qualitative. [11] Suggested that we should use qualitative research when numerical measurement becomes either undesirable or impossible. [5] and [12] recommend using a combination of qualitative and quantitative research. [11] argued that the best studies combine both qualitative and quantitative work. They added that good research design is rarely done by isolation from prior research and by harvesting overlooked data or information, researchers can obtain relevant info. Increasing relevant data can include intensive interviews. [13] argued that case studies are applied to learn something new about something known to a degree, not for learning something completely new. [14] argued that case studies are a way to do an in-depth single unit study to generalize similar larger class (like a sample of a population).

\section{References}

1. Harbom, Lotta and and Peter Wallensteen. 2010. "Armed Conflict and Peace Agreements." Journal of Peace Research 47 (4), 501-509.

2. Collier, Paul, and Anke Hoeffler, "Greed and Grievance in Civil War." CSAE Working Paper Series WPS, 2002, 01, 1-43.

3. Fearon, James D., and David D. Laitin. 2003. "Ethnicity, Insurgency, and Civil War."American Political Science Review, 97 (1), 75-90.

4. Collier, Paul, and Nicholas Sambanis. 2005. “Understanding Civil War: A New Agenda.” Journal of Conflict Resolution, 46 (1), 3-12.

5. Fox, Jonathan. "The Effects of Religious Discrimination on Ethnoreligious Protest and Rebellion.", 2000, http://www.lib.unb.ca/Texts/JCS/Fall00/Fox.htm

6. Juergensmeyer, Mark, Terror in the Mind of God: The Global Rise of Religious Violence. Berkeley: University of California Press, 2001.

7. Vanhanen, Tatu, "Domestic Ethnic Conflict and Ethnic Nepotism: A Comparative 
Analysis.” Journal of Peace Research 1999, 36 (1), 55-73.

8. Halliday, Fred, "Islam and the Myth of Confrontation: Religion and Politics in the Middle East". London: I.B. Tauris and Co. Ltd, 1996.

9. Gleditsch, Nils Petter, and Henrik Urdal, "Ecoviolence? Links Between Population Growth, Environmental Scarcity and Violent Conflict in Thomas Homer-Dixon's Work." Journal of International Affairs , 2002, 56 (1), 283-303.

10. Hegre, Håvard, Scott Gates, Nils P. Gleditsch and Tanja Ellingsen, "Toward a Democratic Civil Peace? Democracy, Political Change and Civil War 1816-1992." American Political Science Review , 2001, 95(1), 33-48.

11. Keohane, Robert O., Gary King, and Sidney Verba, "The Importance of Research Design in Political Science.” The American Political Science Review, 1995, 89 (2), 475-481.

12. Collier, Paul, and Nicholas Sambanis, eds. "Understanding Civil War: Evidence and Analysis". Washington: The World Bank,2005, 1.

13. McKeown, Timothy J. 1999. "Case Studies and the Statistical Worldview: Review of King, Keohane, and Verba's Designing Social Inquiry: Scientific Inference in Qualtitative Research." International Organization, 1999, 53 (1), 161-190.

14. Gerring, John, "What is Case Study and What is it Good For?" American Political Science Review, 2004, 98 (2), 341-354. 